\title{
CEO Overconfidence and Risk-Taking Behaviour in Indonesian Banking Sectors
}

\author{
Darus Altin ${ }^{1}$, Jakaria ${ }^{2}$ \\ \{altin@ubb.ac.id\} \\ Faculty of Economics and Business, Bengkulu University, Bengkulu, Indonesia ${ }^{1}$ \\ Faculty of Economics and Business, Trisakti University, Jakarta, Indonesia ${ }^{2}$
}

\begin{abstract}
The regional governments make organizational decisions that must be in line with goal setting. The government management system is expected to focus on increasing accountability while improving results-oriented performance (outcome) at the same time. Cascading is a process of decreasing and aligning organizational targets to work units at all levels in the organization in a hierarchical manner. This process can be carried out to the lowest level, namely to the individual level. Therefore, there is an alignment of roles at all levels of the organizational unit. Cascading carried out in the regional government greatly affects the performance of the regional government in the Government Agency Performance Accountability System (Indonesian: Sistem Akuntabilitas Kinerja Instansi Pemerintah (SAKIP)). The purpose of this study was to find out the implementation of cascading in the regional governments of Kerinci Regency, Jambi Province and Rejang Lebong Regency, Bengkulu Province, in realizing a clean, accountable, and high-performing government. In this study, researchers applied a qualitative approach with a descriptive analysis method. The results showed that, in general, cascading has been carried out to improve the quality of governance in Kerinci Regency, Jambi Province and Rejang Lebong Regency, Bengkulu Province. However, the implementation of cascading in achieving the Key Performance Indicators (KPIs) for Regional Heads still needs to be revised or improved so that all Regional Apparatus Organizations (Indonesian: Organisasi Perangkat Daerah (OPD)) can align the KPIs for Regional Heads with the KPIs for Regional Apparatus Organizations to attain the vision and mission of the regional government.
\end{abstract}

Keywords: Cascading; Performance Planning; Key Performance Indicators; Performance Report

\section{Introduction}

Bank needs for good corporate governance practice increase as the complexity of risk as faced by the bank escalates. The study of risk-taking behaviour is inseparable from psychological studies that assess the individual aspect as the main actor in decision-making. Adams, Almeida and Ferreira, (2005) suggest that the high risk will increase the CEO's power 
to make decisions that impact the occurrence of greater risk. The purpose of this research is to create a model of risk taking behavior in Indonesian banks.

We propose a model for bank risk taking behavior in Indonesia due to the limited number of previous studies related to the effect of CEO Overconfidence on bank risk taking behaviour. Prior studies showed the effect of CEO overconfidence on bank risk taking, and among them were carried out by Niu (2010a), (2010b). Studies on the effect of CEO Overconfidence have been conducted on various variables, including on the investment decisions (Malmendier and Tate, 2005), company acquisition decisions in Australia (Brown and Sarma, 2007), merger decisions (Malmendier and Tate, 2008), corporate innovation (Galasso and Simcoe, 2011), capital structure (Malmendier, Tate, and Yan, (2011), the accuracy of financial reporting (Schrand and Zechman (2012), corporate debt growth (Ho, Huang, Lin, and Yen, 2016), and the value of the company's cash holding (Aktas et al., 2019). With these various considerations, it is still necessary to study the effect of CEO Overconfidence on bank risk taking in Indonesia.

In Attribution Theory; Self-Serving Biases, it is argued that success is associated with factors from the individual himself when there is a positive evaluation of job performance. However, it will be associated with factors from outside the individual if there is a negative evaluation of the low success of a job. Several previous studies have contributed to selfserving bias theory, including the study of overconfidence and self-serving bias in developing the social and experimental psychological literature (Miller and Ross, 1975); Svenson (1981); Larwood and Whittaker (1977); and (Malmendier and Tate, 2015). Next, Svenson (1981). The development of studies on bias from overconfidence continues to develop and become a concern for researchers in the field of economics and finance (Malmendier and Tate, 2005a; Brown and Sarma, 2007; Malmendier and Tate, 2008; Galasso and Simcoe, 2011 Schrand and Zechman (2012); Hribar and Yang (2016) Aktas, Louca, and Petmezas (2019) Niu, (2010a), (2010b) and Ho, Huang, Lin, and Yen (2016).

We used a sample of 1,007 bank-year observations in Indonesia from 2000-2018, and have the banks grouped into 4 categories of $B U K U$ (Commercial Banks Based on Business Classifications). BOOK 1 consists of 114 observations, BOOK 2 has 475 obs, BOOK 3 comprises of 304 obs, and BOOK 4 has 114 obs. Bank categorization is calculated by considering the amount of core capital of the bank in the last year of research (2018). The calculation of bank core capital is calculated based on the definition of categorization as stated by the financial service authority regulation (POJK Number 6 / POJK.03 / 2016, 2016).

\section{Literature Review}

Each individual has various aspects of selfish bias where their self-confidence is seen as more capable than the reality or tends to be overconfident. Bradley (1978) experimentally examined the success or failure of a task that will significantly affect individuals where the positive effect is in the form of success and the negative effect is failure. If it is extended to the organizational level, it will lead to overly optimistic and risky planning for the future (Larwood and Whittaker, 1977). The study of risk taking has also examined the determinants of individual behavioral motivation. Atkinson, (1957) explained how the motives for achieving success and avoiding failure can influence risk-taking behavior.

The concept of overconfidence is used to distinguish the overestimation bias with respect to a country's performance measures, such as economic growth (Malmendier and Tate, 2008). Another study shows a new measure of CEO overconfidence in business innovation (Galasso 
\& Simcoe, 2011). Hribar and Yang (2016) found that overconfident CEOs tend to make inaccurate forecasting decisions in the future. Aktas, Louca and Petmezas (2019) reveal that the CEO's overconfidence affects the value of cash and has implications for corporate investment policies. Studies examining the direct effect of the CEO's overconfidence in taking bank risks, including: Niu, (2010a) have shown that overconfidence in the CEO has a significant effect on hiring of banking risks, especially for banks with large total assets. Previous studies have examined the effect of managers' overconfidence on the sensitivity of the influence of cash flows on investment decisions of manufacturing companies listed on the Indonesian stock exchange (Santi, 2016). Most of the studies on the effect of CEO overconfidence regarding risk taking by banks have also been conducted in banks in the United States (Niu, 2010a), (Niu, 2010b) and (Ho, Huang, Lin and Yen, 2016)

\section{CEO Overconfidence and Bank Risk Taking}

It is assumed that each individual has various aspects of egocentric bias (Miller and Ross, 1975), where their self-confidence is seen as more capable than the reality or tends to be overconfident (Larwood and Whittaker, 1977), by calibrating abilities, competencies and the need to maintain a positive image that indicates a person's behavior to be better (Alicke, 1985). Based on the assumptions that have been developed from the above studies, it shows that the overconfidence behavior has a "better than average" effect due to the presence of more expertise than other individuals. This causes the CEO to become overconfidence, thus affecting company decisions, including a significant effect on the sensitivity of investing in cash flow (Malmendier and Tate, 2005), influencing company decisions related to acquisitions (Brown and Sarma, 2007), and influencing cash flow and company capabilities to go into debt without having risk, so that it may have an impact on the company's decision to merge (Malmendier and Tate, 2008).

With regard to risk taking, there is a strong tendency for individuals to be more confident in showing their skills than other people, causing greater risk taking (Svenson, 1981) and overconfidence behavior that may cause individuals to prefer risk because it is considered to be able to beat the chance of this risk (Camerer). and Lovallo, 1999). CEO overconfidence tends to be more willing to take risks when assessing projects than rational managers (Hackbarth, 2009) and more concerned about company-specific risks (Gervais, Simon., Heaton, and Odena, 2003); more daring to take project risks with consequences for doing different things so that they are more promoted to CEO but are too invested (Goel and Thakor, (2008); and will benefit the company and commit to using high costs because they have stronger and motivated efforts to working on risky projects (Gervais, Heaton, and Odean, (2011) Niu, (2010a), (2010b). It also develops the assumptions and the results of previous research (Gervais, Simon., Heaton, and Odena, 2003; Goel and Thakor 2008; Hackbarth, 2009) shows that overconfidence CEO has a positive effect on banking risk taking. Based on the assumptions and results of previous research, the following hypothesis is proposed:

Hypothesis : CEO Overconfidence has a positive effect on bank risk taking

\section{Research Method}

\subsection{Data and Sample}


The data and samples used in our research were taken from the annual and financial reports obtained from ThombsonOneBaker, Bloomberg, and banks' websites in Indonesia from 2000 to 2018. The number of annual reports obtained depends on the completeness of data availability of bank's websites. The data requirement refers to the financial data of bank risk (credit risk, market risk, operational risk and liquidity risk) and banking asset data. Other data refers to CEO profiles, bank share ownership, data regarding the composition of the company's board of commissioners, and board of directors from the year. 2000 to 2018.

The population of this research is commercial banks in Indonesia with a total of 94 commercial banks. The sample with complete data to be processed is reported to be 53 banks, classified according to the group of Commercial Banks based on Business Activities (BUKU) which are divided into 6 banks in the category of $B O O K 1,25$ bank in $B O O K 2,16$ banks in $B O O K$ 3, and 6 banks in $B O O K$ 4. Bank grouping including BOOK 1, BOOK 2, BOOK 3 and $B O O K 4$ were performed by calculating the amount of core capital of the bank in the last year of research (2018). The calculation of the core capital of banks in Indonesia is calculated based on the reference of the Financial Services Authority Regulation (POJK): Number 6 / POJK.03 / 2016, 2016).

\subsection{Operationalisation Variables}

This study uses 11 variables in total. The dependent variables are NPL, NIM, BOPO, LDR. The independent variables are CEO OVERCONFIDENCE Meanwhile, the control variables are BANKSIZE, BOARDSIZE, OWN1, OWN1-2, OWN1-5 and COM.

Tabel 1. Operationalisation of Variables

\begin{tabular}{|c|c|c|}
\hline Variables & Operationalization and measurements & Tine dato \\
\hline NPL & NPL is a proxy for bank credit risk. Credit risk is proxied by & Ratio \\
\hline NIM & $\begin{array}{l}\text { NIM is a proxy for the bank's market risk. Market risk is } \\
\text { proxied by the Net Interest Margin (NIM) ratio with the } \\
\text { formula: NIM = Net interest income / average eaming assets }\end{array}$ & Ratio \\
\hline BOPO & $\begin{array}{l}B O P O \text { is a proxy for bank operational risk. Operational risk } \\
\text { is calculated by the formula Operating Expenses to } \\
\text { Operating Income }(B O P O)=\text { total operating expenses / total } \\
\text { operating income } x 100 \%\end{array}$ & Ratio \\
\hline LDR & $\begin{array}{l}\text { LDR is a proxy for bank liquidity risk. Liquidity risk is proxied } \\
\text { by the Loan to Deposit Ratio (LDR), formulated from the } \\
\text { calculation: total credit divided by total bank fund receipts. }\end{array}$ & Ratio \\
\hline $\begin{array}{c}\text { CEO } \\
\text { OVERCONFIDENCE }\end{array}$ & $\begin{array}{l}\text { Measurement of CEO overconfidence is carried out using } \\
\text { two managerial overconfidence proxies from bank-specific } \\
\text { scores (namely OC_BANK4 and OC_BANK5) which are } \\
\text { constructed from five components of investment activity, } \\
\text { funding activity and dividend policy at the bank level, as a } \\
\text { proxy for managerial overconfidence. Executives who are } \\
\text { overconfident are consistently optimistic across the context } \\
\text { of corporate decisions }\end{array}$ & Dummy $(0 ; 1)$ \\
\hline BANK_SIZE & Measured from the natural logarithm of total assets & Ratio \\
\hline BOARD_SIZE & $\begin{array}{l}\text { Measured by the number of members of the board of } \\
\text { directors and board of commissioners }\end{array}$ & Ratio \\
\hline OWN1 & The largest percentage of share ownership & Ratio \\
\hline OWN1-2 & Largest shareholding percentage, Rank 1 to 2 & Ratio \\
\hline OWN1-5 & Largest shareholding percentage, Rank 1 to 5 & Ratio \\
\hline COM & $\begin{array}{l}\text { Percentage of independent commissioners on the board of } \\
\text { commissioners }\end{array}$ & Ratio \\
\hline
\end{tabular}

\subsection{Regresi Model Data Panel}

Panel data analysis is employed by firstly describing the descriptive statistics information of each variable. Also, in the next step, we test the model specifications. We performed the 
test using Eviews (Pooled Least Square) to prove the research hypothesis. The statistical models developed in this study are available as follows:

The effect of CEO Overconfidence on bank risk taking without involving control variables:

$\mathrm{R}_{\mathrm{it}}=\mu+\beta_{l} \mathrm{O}_{i, t}+\varepsilon_{i, t}$

The effect of CEO Overconfidence on bank risk taking by involving control variables:

$\mathrm{R}_{\mathrm{it}}=\mu+\alpha_{\mathrm{i}}+\beta_{l} \mathrm{O}_{i, t} \sum_{j=6} \beta_{j} Z_{j, i, t-1}^{1}+\varepsilon_{i, t}$

Ri, $t$ represents four variable measures of bank risk taking, namely credit risk (NPLi, $t$ ), market risk (NIMi, $t)$, operational risk $(B O P O i, t)$, and liquidity risk (LDRi, $t$ ) for bank $i$ and year $\mathrm{t}$. Oi, $\mathrm{t}$ is an overconfident dummy variable which has a value of one if bank $\mathrm{i}$ is an overconfident bank, and zero if bank $\mathrm{i}$ is a non-overconfident bank at time $t$. $Z^{1}$ is the six characteristics of the controlled bank in this study: BANKSIZE, BOARDSIZE, OWN1, OWN1-2, OWN1-5, COM عi, $\mathrm{t}$ are random errors.

\section{Result}

\subsection{Summary of Statistics}

First, we present the general information for the dependent variable and the independent variables. The sample of our study consists of banks classified as $B O O K 1, B O O K 2, B O O K 3$ and $B O O K$ 4. This classification aims to prove the proposed hypotheses 1, 2 and 3 towards bank risk behaviour in the four $B U K U \mathrm{~s}$ of categorizations. The sample classifications included in the four $B U K U$ s are presented in Table 2.

Table 2. Banks in Indonesia based on Commercial Bank Business Classification $(B O O K)$

\begin{tabular}{ccc}
\hline Bank classification & Number of banks & Observations \\
\hline BOOK_1 & 6 & 114 \\
BOOK_2 & 25 & 475 \\
BOOK_3 & 16 & 304 \\
BOOK_4 & 6 & 114 \\
Total & 53 & 1007 \\
\hline
\end{tabular}

\subsection{Descriptive Statistics}

Descriptive statistics of all the variables we used in this study are shown in Table 3 . The risk description of banks from $B O O K 1$ to $B O O K 4$ classification can be explained as follows: the average NPL / Nplloan is still below $5 \%$, the mean NIM is above $2 \%$, the BOPO of all banks is seen to be less than $95 \%$, and the average value -The average LDR ratio ranges from> $=75 \%$, to $>=85 \%$. Based on Bank Indonesia decrees, on average bank risk can be categorized as healthy banking (Bank Indonesia, 2011). Not all banks in BOOK 1 to BOOK 4 are led by overconfidence CEOs. In detail, $47 \%$ of all banks in $B O O K 1$ were led by CEO Overconfidence, $54 \%$ of all banks in $B O O K 2$ were led by CEO Overconfidence, $66 \%$ of all banks in $B O O K 3$ were led by CEO Overconfidence and the largest, namely: $90 \%$ of all banks in $B O O K 4$ led by CEO Overconfidence. The highest average size of the board of directors, 
the largest bank size and the largest average shareholding ranked 1 and 1-2 were in $B O O K 4$ banks.

\subsection{The Impact of CEO Overconfidence on Bank Risk}

We provide the regression results of CEO Overconfidence on bank risk in Table 4. In detail, the findings of hypothesis 1 will be translated into the following two main findings. First, from model 1a, it is found that CEO Overconfidence has a positive and significant effect on NIMs in banks classified as BOOK 2, BOOK 3 and BOOK 4; on BOPO in BOOK 1, BOOK 2 and $B O O K$ 3; and on LDR in $B O O K 1$ and $B O O K$ 2. Model $1 \mathrm{~b}$ found that CEO Overconfidence had a positive and significant effect on NPLLOAN only for banks classified as $B O O K$ 4; against $B O P O$ in $B O O K$ 3; and on LDR in $B O O K 1, B O O K 2$ and BOOK 4. The findings of hypothesis 1 which show that CEO overconfidence has a positive and significant effect on the four bank risks are consistent with the results of Niu (2010a) and Niu (2010b) 's research, proving that overconfidence CEO has a significant effect on decision making, especially for banks with large total assets.

Second, from the results of hypothesis testing 1, equation 1.a, it is found that CEO Overconfidence has no effect on NPLLOAN in banks classified as $B O O K 1$ to $B O O K 4$; against NIM in BOOK 1; to BOPO in $B O O K$ 4, and to LDR in BOOK 3 and BOOK 4. While the findings from the results of hypothesis 1 test of equation 1.b are that CEO Overconfidence has no effect on NPLLOAN in banks classified as $B O O K 1, B O O K 2$ and $B O O K$ 3; against NIM in $B O O K 1$ to $B O O K$ 4; against $B O P O$ in $B O O K$ 1, $B O O K$ 2, $B O O K$ 4; and on LDR in $B O O K$ 3. The findings of CEO Overconfidence that do not affect the four bank risk variables are not consistent with the findings of Ho, Huang, Lin, and Yen (2016), where in their findings that overconfidence CEO tends to have a significant effect on Non-Performing Loans ( NPL) as indicated by a more aggressive lending decision making. The findings of CEO overconfidence that do not affect NPLLOAN in all BUKUs can be said that overconfidence reflects overestimation and is assumed to be more resistant or insensitive to risk. This finding supports the findings of Moore, (1977); Camerer and Lovallo, (1999); Gervais, Simon., Heaton, and Odena, (2003); (Malmendier and Tate, 2005). (Hackbarth, 2009) and (Gervais, Heaton, and Odean, (2011). 
Table 3. Summary of descriptive statistics for the dependent variable,

independent variable and control variable

\begin{tabular}{|c|c|c|c|c|c|c|}
\hline Variable & Obs & Mean & Median & Max & Min & Std dev \\
\hline \multicolumn{7}{|l|}{ Dependent Variable: } \\
\hline \multicolumn{7}{|l|}{ NPLLOAN } \\
\hline BOOK_1 & 114 & 1.79 & 1.45 & 9.92 & 0.00 & 0.85 \\
\hline$B O O K 2$ & 475 & 1.65 & 1.02 & 14.00 & -3.90 & 0.89 \\
\hline$B O O K 3$ & 304 & 1.59 & 1.29 & 8.00 & 0.00 & 0.49 \\
\hline$B O O K \quad 4$ & 114 & 1.23 & 0.88 & 6.00 & 0.12 & 0.66 \\
\hline \multicolumn{7}{|l|}{ NIM } \\
\hline$B O O K_{1} I$ & 114 & 7.70 & 7.09 & 25.37 & 3.50 & 1.27 \\
\hline$B O O K 2$ & 475 & 7.03 & 6.14 & 26.59 & -0.65 & 1.42 \\
\hline$B O O K \quad 3$ & 304 & 6.07 & 5.29 & 21.84 & -4.19 & 0.96 \\
\hline$B O O K \quad 4$ & 114 & 5.94 & 5.62 & 12.64 & -1.21 & 0.74 \\
\hline \multicolumn{7}{|l|}{$B O P O$} \\
\hline$B O O K \quad 1$ & 114 & 84.04 & 82.76 & 206.69 & 49.17 & 11.08 \\
\hline$B O O K 2$ & 475 & 88.69 & 85.12 & 464.01 & 25.53 & 18.43 \\
\hline$B O O K \quad 3$ & 304 & 85.03 & 83.85 & 219.00 & 0.00 & 12.74 \\
\hline$B O O K \quad 4$ & 114 & 79.45 & 74.80 & 183.20 & 55.58 & 8.27 \\
\hline \multicolumn{7}{|l|}{ LDR } \\
\hline$B O O K \_1$ & 114 & 82.47 & 88.15 & 173.52 & 17.38 & 12.64 \\
\hline$B O O K 2$ & 475 & 77.35 & 81.66 & 295.76 & 0.00 & 11.63 \\
\hline$B O O K_{3} 3$ & 304 & 81.22 & 83.51 & 206.35 & 0.00 & 7.99 \\
\hline$B O O K$ & 114 & 70.63 & 72.19 & 129.17 & 9.28 & 5.70 \\
\hline \multicolumn{7}{|l|}{ Independent Variable: } \\
\hline \multicolumn{7}{|c|}{ CEO Overconfidence measured by OC BANK4 } \\
\hline$B O O K \quad 1$ & 54 & 2.84 & 3.00 & 5.00 & 1.00 & 1.27 \\
\hline$B O O K_{2} 2$ & 258 & 13.58 & 13.00 & 19.00 & 8.00 & 2.72 \\
\hline$B O O K=3$ & 200 & 10.53 & 11.00 & 15.00 & 8.00 & 1.76 \\
\hline$B O O K 4$ & 103 & 5.42 & 5.00 & 6.00 & 4.00 & 0.59 \\
\hline \multicolumn{7}{|c|}{ CEO Overconfidence measure by OC_BANK5 } \\
\hline$B O O K_{1}{ }_{1}$ & 41 & 2.16 & 2.00 & 4.00 & 1.00 & 0.93 \\
\hline$B O O K_{2}$ & 211 & 11.11 & 11.00 & 15.00 & 6.00 & 2.10 \\
\hline$B O O K 3$ & 173 & 9.11 & 8.00 & 13.00 & 7.00 & 1.68 \\
\hline$B O O K 4$ & 89 & 4.68 & 5.00 & 6.00 & 4.00 & 0.73 \\
\hline \multicolumn{7}{|l|}{ Control Variable: } \\
\hline \multicolumn{7}{|l|}{ Bank_Size } \\
\hline$B O O K \quad 1$ & 114 & 13.87 & 14.16 & 15.77 & 11.27 & 0.21 \\
\hline$B O O K 2$ & 475 & 14.88 & 15.03 & 17.26 & 9.77 & 0.30 \\
\hline$B O O K_{3} 3$ & 304 & 16.95 & 17.29 & 19.45 & 11.57 & 0.45 \\
\hline BOOK_4 & 114 & 19.07 & 19.34 & 20.93 & 16.58 & 0.18 \\
\hline \multicolumn{7}{|l|}{ Board Size } \\
\hline$B O O K \quad 1$ & 114 & 7.00 & 7.00 & 10.00 & 4.00 & 0.38 \\
\hline$B O O K \_2$ & 475 & 8.00 & 7.00 & 15.00 & 3.00 & 0.29 \\
\hline$B O O K_{3} 3$ & 304 & 11.00 & 11.00 & 22.00 & 4.00 & 0.71 \\
\hline$B O O K \quad 4$ & 114 & 16.00 & 17.00 & 21.00 & 9.00 & 0.39 \\
\hline \multicolumn{7}{|l|}{ OWN1 } \\
\hline$B O O K \_1$ & 114 & 50.22 & 47.85 & 99.00 & 22.00 & 3.17 \\
\hline$B O O K 2$ & 475 & 60.16 & 59.16 & 100.00 & 16.24 & 1.14 \\
\hline$B O O K 3$ & 304 & 62.25 & 59.20 & 100.00 & 20.27 & 1.13 \\
\hline$B O O K 4$ & 114 & 63.65 & 59.87 & 100.00 & 37.94 & 4.60 \\
\hline \multicolumn{7}{|l|}{ OWN2 } \\
\hline$B O O K \_1$ & 114 & 67.32 & 64.88 & 100.00 & 38.40 & 2.44 \\
\hline$B O O K=2$ & 475 & 80.32 & 87.69 & 100.00 & 24.53 & 1.80 \\
\hline$B O O K \_3$ & 304 & 84.07 & 93.41 & 100.00 & 40.54 & 1.40 \\
\hline$B O O K \quad 4$ & 114 & 93.02 & 95.52 & 100.00 & 71.10 & 2.10 \\
\hline \multicolumn{7}{|l|}{ OWN5 } \\
\hline$B O O K \_1$ & 114 & 88.43 & 91.44 & 100.00 & 62.68 & 1.60 \\
\hline$B O O K \_2$ & 475 & 93.46 & 100.00 & 100.00 & 37.20 & 3.05 \\
\hline$B O O K=3$ & 304 & 96.77 & 100.00 & 100.00 & 63.17 & 1.09 \\
\hline$B O O K \quad 4$ & 114 & 96.05 & 100.00 & 100.00 & 96.08 & 0.43 \\
\hline
\end{tabular}


Tabel 4. Regression of CEO Overconfidence on bank risk

\begin{tabular}{|c|c|c|c|c|}
\hline & \multicolumn{4}{|c|}{ Panel A. Dependent Variable: NPLLLOAN } \\
\hline & BOOK_1 & BOOK_2 & BOOK_3 & BOOK_4 \\
\hline $\begin{array}{l}\text { Model 1a. } \\
\text { OC_BANK4 (OB4) } \\
\text { Adj R } \text { R }^{2}\end{array}$ & $\begin{array}{l}0.0001^{\star} \\
0.0370\end{array}$ & $\begin{array}{l}0.0005^{\star} \\
0.4578\end{array}$ & $\begin{array}{l}0.0002^{\star} \\
0.4051\end{array}$ & $\begin{array}{l}0.0004^{\star} \\
0.2059\end{array}$ \\
\hline $\begin{array}{l}\text { OC_BANK5 (OB5) } \\
\text { Adj } R^{2}\end{array}$ & $\begin{array}{l}0.0018^{\star} \\
0.0430\end{array}$ & $\begin{array}{l}0.0006^{\star} \\
0.4682\end{array}$ & $\begin{array}{l}-4.7300^{\star} \\
0.4020\end{array}$ & $\begin{array}{l}-0.0026^{\star} \\
0.2435\end{array}$ \\
\hline $\begin{array}{l}\text { Model 1b. } \\
\text { OC_BANK4 (OB4) } \\
\text { BANK_SIZE } \\
\text { BOARD_SIZE } \\
\text { OWN1 } \\
\text { OWN2 } \\
\text { OWN5 } \\
\text { COM } \\
\text { Adj R } \\
\text { OC_BANK5 (OB5) } \\
\text { BANKK_SIZE } \\
\text { BOARD_SIZE } \\
\text { OWN1 } \\
\text { OWN2 } \\
\text { OWN5 } \\
\text { COM } \\
\text { Adj R }\end{array}$ & $\begin{array}{l}-0.0015^{\star} \\
0.0045^{\star} \\
-0.2981^{\star \star \star} \\
0.0066^{\star} \\
\text { NA } \\
0.0236^{\star} \\
-0.0116^{\star} \\
0.0533 \\
0.0003^{\star} \\
0.0043^{\star} \\
-0.2633^{\star} \\
0.0061^{\star} \\
N A \\
0.0256^{\star} \\
-0.0120^{\star} \\
0.0531\end{array}$ & 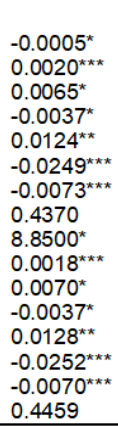 & 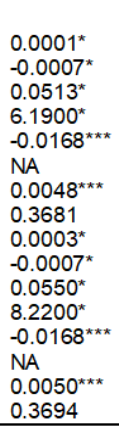 & $\begin{array}{l}0.0007^{\star} \\
-0.0014^{\star} \\
-0.1778^{\star} \\
-0.0054^{\star} \\
0.0127^{\star} \\
0.1191^{\star} \\
0.0167^{\star} \\
0.2866 \\
-0.0034^{\star} \\
-0.0013^{\star} \\
-0.1982^{\star \star} \\
-0.0045^{\star} \\
0.0122^{\star} \\
0.1350^{\star} \\
0.0185^{\star} \\
0.3230 \\
\end{array}$ \\
\hline & \multicolumn{4}{|c|}{ Panel B. Dependent Variable: NIM } \\
\hline $\begin{array}{l}\text { Model 1a. } \\
\text { OC_BANK4 (OB4) } \\
\text { Adj R } \\
\text { OC_BANK5 (OB5) } \\
\text { Adj R R }\end{array}$ & $\begin{array}{l}-0.0046^{\star} \\
0.3582 \\
-0.0016^{\star} \\
0.3512\end{array}$ & $\begin{array}{l}-0.0028^{\star} \\
0.6818 \\
-0.0011^{\star} \\
0.6712\end{array}$ & $\begin{array}{l}-0.0045^{\star \star \star \star} \\
0.5009 \\
-0.0016^{\star} \\
0.4914\end{array}$ & $\begin{array}{l}-0.0026^{\star} \\
0.4356 \\
-0.0045^{\star} \\
0.4772\end{array}$ \\
\hline $\begin{array}{l}\text { Model 1b. } \\
\text { OC_BANK4 (OB4) } \\
\text { BANK_SIZE } \\
\text { BOARD_SIZE } \\
\text { OWN1 } \\
\text { OWN2 } \\
\text { OWN5 } \\
\text { COM } \\
\text { Adj R² }\end{array}$ & $\begin{array}{l}-0.0003^{\star} \\
-0.0110^{\star \star \star \star} \\
0.1471^{\star} \\
0.0009^{\star} \\
\text { NA } \\
-0.0014^{\star} \\
0.0038^{\star} \\
0.4402\end{array}$ & $\begin{array}{l}-0.0016^{\star} \\
-0.0095^{\star \star \star \star} \\
0.4408^{\star \star \star \star} \\
0.0012^{\star} \\
-0.0094^{\star} \\
-0.0247^{\star} \\
0.0047^{\star} \\
0.7330\end{array}$ & $\begin{array}{l}0.0019^{\star} \\
-0.0059^{\star \star \star \star} \\
0.1953^{\star} \\
-0.0550^{\star \star \star \star} \\
0.0563^{\star \star \star} \\
\text { NA } \\
0.0122^{\star} \\
0.5834\end{array}$ & $\begin{array}{l}-0.0057^{\star} \\
-0.0024^{\star} \\
0.6610^{\star} \\
-0.0010^{\star} \\
-0.0372^{\star} \\
0.0015^{\star} \\
0.0507^{\star} \\
0.3341\end{array}$ \\
\hline $\begin{array}{l}\text { OC_BANK5 (OB5) } \\
\text { BANK_SIZE } \\
\text { BOARD_SIZE } \\
\text { OWN1 } \\
\text { OWN2 } \\
\text { OWN5 } \\
\text { COM } \\
\text { Adj R }{ }^{2} \\
\end{array}$ & $\begin{array}{l}0.0005^{\star} \\
-0.0110^{\star \star \star \star} \\
0.1703^{\star} \\
0.0006^{\star} \\
\text { NA } \\
-0.0024^{\star} \\
0.0037^{\star} \\
0.4381 \\
\end{array}$ & $\begin{array}{l}-0.0005^{\star} \\
-0.0095^{\star \star \star} \\
0.4459^{\star \star \star \star} \\
0.0019^{\star} \\
-0.0105^{\star} \\
-0.0243^{\star} \\
0.0041^{\star} \\
0.7271 \\
\end{array}$ & $\begin{array}{l}0.0024^{\star} \\
-0.0060^{\star \star \star \star} \\
0.1977^{\star \star} \\
-0.0545^{\star \star \star \star} \\
0.0544^{\star \star \star} \\
\text { NA } \\
0.0130^{\star} \\
0.5835 \\
\end{array}$ & $\begin{array}{l}-0.0022^{\star} \\
-0.0018^{\star} \\
0.6060^{\star} \\
0.0005^{\star} \\
-0.0283^{\star} \\
-0.0455^{\star} \\
0.0481^{\star} \\
0.3273 \\
\end{array}$ \\
\hline & \multicolumn{4}{|c|}{ Panel C. Dependent Variable: $B O P O$} \\
\hline $\begin{array}{l}\text { Model 1a. } \\
\text { OC_BANK4 (OB4) } \\
\text { Adj R } \\
\text { OC_BANK5 (OB5) } \\
\text { Adj R R }\end{array}$ & $\begin{array}{l}0.0371^{\star} \\
0.2295 \\
0.0565^{\star \star} \\
0.2446\end{array}$ & $\begin{array}{l}-0.0200^{\star \star \star \star} \\
0.4423 \\
-0.0122^{\star} \\
0.4381\end{array}$ & $\begin{array}{l}-0.0181^{\star \star} \\
0.1627 \\
-0.0204^{\star \star \star} \\
0.1654\end{array}$ & $\begin{array}{l}0.0075^{\star} \\
0.1480 \\
-0.0161^{\star} \\
0.1596\end{array}$ \\
\hline Model 1b. & & & & \\
\hline OC_BANK4 (OB4) & $0.0105^{\star}$ & $-0.0084^{\star}$ & $-0.0170^{\star}$ & $0.0132^{\star}$ \\
\hline $\begin{array}{l}\text { BANKK_SIZE } \\
\text { BOARD_SIZE } \\
\text { OWN1 } \\
\text { OWN2 } \\
\text { OWN5 } \\
\text { COM } \\
\text { Adj R² }\end{array}$ & $\begin{array}{l}0.0672^{\star \star \star \star} \\
0.7947^{\star} \\
0.0619^{\star \star} \\
\text { NA } \\
0.1882^{\star} \\
-0.0457^{\star} \\
0.3596\end{array}$ & $\begin{array}{l}0.0029^{\star} \\
-1.1178^{\star \star \star} \\
0.2419^{\star} \\
-0.0794^{\star} \\
-0.1835^{\star \star} \\
-0.0179^{\star} \\
0.4151\end{array}$ & $\begin{array}{l}-0.0062^{\star} \\
-0.8396^{\star} \\
0.0958^{\star} \\
-0.0629^{\star} \\
\text { NA } \\
0.0836^{\star} \\
0.1600\end{array}$ & $\begin{array}{l}-0.0307^{\star} \\
-3.6434^{\star \star \star} \\
0.3009^{\star \star \star \star} \\
0.1272^{\star} \\
-0.6209^{\star} \\
0.1805^{\star} \\
0.4672\end{array}$ \\
\hline
\end{tabular}




\begin{tabular}{|c|c|c|c|c|}
\hline $\begin{array}{l}\text { OC_BANK5 (OB5) } \\
\text { BANK_SIZE } \\
\text { BOARD_SIZE } \\
\text { OWN1 } \\
\text { OWN2 } \\
\text { OWN5 } \\
\text { COM } \\
\text { Adj R } \\
\end{array}$ & $\begin{array}{l}0.0295^{\star} \\
0.0673^{\star \star \star} \\
1.0552^{\star} \\
0.0499^{\star} \\
\text { NA } \\
0.2195^{\star \star} \\
-0.0528^{\star} \\
0.3680\end{array}$ & $\begin{array}{l}-0.0055^{\star} \\
0.0020^{\star} \\
-1.0753^{\star \star} \\
0.2464^{\star \star \star} \\
-0.0893^{\star} \\
-0.1779^{\star \star} \\
-0.0166^{\star} \\
0.4150\end{array}$ & $\begin{array}{l}-0.0192^{\star \star} \\
-0.0068^{\star} \\
-0.8366^{\star} \\
0.1060^{\star} \\
-0.0512^{\star} \\
N A \\
0.0809^{\star} \\
0.1622 \\
\end{array}$ & $\begin{array}{l}-0.0228^{\star} \\
-0.0279^{\star} \\
-3.5760^{\star \star} \\
0.3190^{\star \star \star} \\
0.1438^{\star} \\
-0.4871^{\star} \\
0.1956^{\star \star} \\
0.4901\end{array}$ \\
\hline $\begin{array}{l}\text { Model 1a. } \\
\text { OC_BANK4 (OB4) } \\
\text { Adj R2 } \\
\text { OC_BANK5 (OB5) } \\
\text { Adj R }{ }^{2}\end{array}$ & $\begin{array}{l}-0.0708^{\star} \\
0.2131 \\
-0.1399^{\star \star} \\
0.2703\end{array}$ & $\begin{array}{l}-0.0104^{\star} \\
0.2121 \\
-0.0640^{\star \star \star \star} \\
0.2326 \\
\end{array}$ & $\begin{array}{l}0.0063^{\star} \\
0.4542 \\
0.0114^{\star} \\
0.4649 \\
\end{array}$ & $\begin{array}{l}-0.0055^{\star} \\
0.1165 \\
-0.0326^{\star} \\
0.1130\end{array}$ \\
\hline $\begin{array}{l}\text { Model } 1 \text { b. } \\
\text { OC_BANK4 (OB4) } \\
\text { BANK_SIZE } \\
\text { BOARD_SIZE } \\
\text { OWN1 } \\
\text { OWN2 } \\
\text { OWN5 } \\
\text { COM } \\
\text { Adj R }{ }^{2}\end{array}$ & $\begin{array}{l}-0.1264^{\star \star \star} \\
0.0964^{\star \star \star} \\
-1.0222^{\star} \\
-0.2481^{\star \star} \\
\text { NA } \\
0.3121^{\star} \\
0.2666^{\star \star} \\
0.3131\end{array}$ & $\begin{array}{l}-0.0584^{\star \star \star} \\
0.0974^{\star \star \star} \\
0.3695^{\star} \\
-0.0035^{\star} \\
0.2909^{\star \star} \\
-0.5874^{\star \star \star} \\
0.1186^{\star \star} \\
0.4717\end{array}$ & $\begin{array}{l}0.0034^{\star} \\
0.0249^{\star \star \star} \\
2.0760^{\star \star} \\
-0.1687^{\star \star} \\
-0.1433^{\star \star} \\
N A \\
0.2920^{\star \star \star} \\
0.5302\end{array}$ & $\begin{array}{l}-0.0730^{\star \star \star} \\
0.1141^{\star \star \star} \\
5.135^{\star} \\
-0.0580^{\star} \\
0.1217^{\star} \\
-2.6824^{\star \star} \\
0.5429^{\star \star} \\
0.6333\end{array}$ \\
\hline $\begin{array}{l}\text { OC_BANK5 (OB5) } \\
\text { BANK_SIZE } \\
\text { BOARD_SIZE } \\
\text { OWN1 } \\
\text { OWN2 } \\
\text { OWN5 } \\
\text { COM } \\
\text { Adj R }{ }^{2}\end{array}$ & $\begin{array}{l}-0.1508^{\star \star \star \star} \\
0.0834^{\star \star} \\
0.1282^{\star} \\
-0.2327^{\star \star} \\
\text { NA } \\
0.4203^{\star} \\
0.2490^{\star \star} \\
0.3201\end{array}$ & $\begin{array}{l}-0.0688^{\star \star \star} \\
0.0922^{\star \star \star \star} \\
0.3950^{\star} \\
-0.0096^{\star} \\
0.2969^{\star \star} \\
-0.5403^{\star \star \star} \\
0.1281^{\star \star \star} \\
0.4744\end{array}$ & $\begin{array}{l}0.0166^{\star} \\
0.0235^{\star \star \star} \\
2.1888^{\star \star} \\
-0.1755^{\star \star} \\
-0.1499^{\star \star} \\
N A \\
0.2938^{\star \star \star} \\
0.5320\end{array}$ & $\begin{array}{l}-0.0838^{\star \star \star} \\
0.1259^{\star \star \star} \\
4.8214^{\star} \\
0.0062^{\star} \\
0.2385^{\star} \\
-2.5800^{\star \star} \\
0.5865^{\star \star \star} \\
0.6577\end{array}$ \\
\hline
\end{tabular}

\section{Conclusion}

This study aims to create a model of risk taking behavior for banks in Indonesia. Specifically, we do it in three stages of testing. We prove the effect of CEO overconfidence on banking risk taking in Indonesia. We used a sample of 1007 banks in Indonesia with observations from 2000-2018 in 4 categories of BUKU (Commercial Banks Based on Business Classifications), namely $B O O K 1$ with 114 observations, $B O O K 2$ with 475 obs, $B O O K 3$ for 304 obs and $B O O K 4$ for 114 obs. We find that CEO Overconfidence has a positive effect on bank risk although the positive influence of CEO Overconfidence on bank risk in Indonesia is uneven across the four types of risk in banks classified as $B O O K$ 1, BUKU. 2, BOOK 3 and BOOK 4 .

This study provides the following theoretical contributions. The results of this study can prove one of the behavioral biases, namely overconfidence in influencing risk taking. Furthermore, overconfidence theory predicts that CEO overconfidence behavior tends to be stronger in risk taking. The prediction of overconfidence theory can be proven from the positive influence of CEO Overconfidence in bank risk taking. This study found that the strong tendency of overconfidence CEOs to be more courageous in taking risks and the importance of the role of a diverse board of directors will determine the quality of bank risk taking. This study still has several limitations. First, the appointment of a CEO is generally selected individuals with a good track record from previous experience as a CEO in banking or a CEO in a non-bank company. CEO practice obtained from two types of business entities with different characteristics, between non-bank and banking companies, will certainly impact the quality of decisions a CEO will take. For this reason, the experience factor has not been studied in more depth, and this could be an opportunity for further research. 


\section{References}

[1] Adams, B., Almeida, H., \& Ferreira, D. (2005). Powerful CEOs and Their Impact on Corporate Performance. The Review of Financial Studies, 18(4). https://doi.org/https://doi.org/10.1093/rfs/hhi030

[2] Aktas, N., Louca, C., \& Petmezas, D. (2019). CEO Overconfidence and The Value of Corporate Cash Holdings. Journal of Corporate Finance, 54(September 2018), 85106. https://doi.org/https://doi.org/10.1016/j.jcorpfin.2018.11.006

[3] Alicke, M. D. (1985). Personality Processes and Individual Differences - Global SelfEvaluation as Determined by the Desirability and Controllability of Trait Adjectives. Journal of Personality and Social Psychology, 49(6), 1621-1630.

[4] Atkinson, J. W. (1957). Motivational Determinants of Risk-Taking Behavior. Psychological Review, 64(6 PART 1), 359-372. https://doi.org/10.1037/h0043445

[5] Bank Indonesia. (2009). Peraturan Bank Indonesia Nomor:11/19/PBI/2009. Bank Indonesia.

[6] Bank Indonesia. (2011). Peraturan Bank Indonesia No.13/1/PBI/2011 Tentang Penilaian Tingkat Kesehatan Bank. In bank Indonesia (pp. 1-31).

[7] Berger, A. N., Kick, T., \& Schaeck, K. (2013). Executive Board Composition and Bank Risk Taking. Journal of Corporate Finance, Corfin-00736, 1-18. https://doi.org/https://doi.org/10.1016/j.jcorpfin.2013.11.006

[8] Bradley, G. W. (1978). Self-serving biases in the attribution process: A reexamination of the fact or fiction question. Journal of Personality and Social Psychology, 36(1), 56-71. https://doi.org/10.1037/0022-3514.36.1.56

[9] Brown, R., \& Sarma, N. (2007). CEO Overconfidence , CEO Dominance and Corporate Acquisitions. Journal of Economics and Business, 59, 358-379. https://doi.org/https://doi.org/10.1016/j.jeconbus.2007.04.002

[10] Camerer, C., \& Lovallo, D. (1999). Overconfidence and Excess Entry: An Experimental Approach. American Economic Review, 89(1), 306-318. https://doi.org/DOI:10.1257/aer.89.1.306

[11] Faccio, M., Marchica, M. T., \& Mura, R. (2016). CEO Gender, Corporate Risk-Taking, and The Efficiency of Capital Allocation. Journal of Corporate Finance, 39, 193-209. https://doi.org/10.1016/j.jcorpfin.2016.02.008

[12] Galasso, A., \& Simcoe, T. (2011). CEO Overconfidence and Innovation. Management Science, 57(8), 1469-1484. https://doi.org/doi 10.1287/mnsc.1110.1374

[13] Gervais, Simon., Heaton, J.B., Odena, T. (2003). Oerconfidence, Invesment Policy, and Executive Stock Options (Issue 312).

[14] Gervais, S., Heaton, J. B., \& Odean, T. (2011). Overconfidence , Compensation Contracts , and Capital Budgeting. Journal of Finance, LXVI(5), 1735-1777. https://doi.org/https://doi.org/10.1111/j.1540-6261.2011.01686.x

[15] Goll, Irene., Sambharya, Rakesh B., Tucci, L. A. (2001). Top Management Team Composition, Corporate Ideology, and Firm Performance. Management International Review, 41(2), 109-129. 
[16] Hackbarth, D. (2009). Determinants of Corporate Borrowing: A Behavioral Perspective. Journal of Corporate Finance, 15(4), 389-411. https://doi.org/10.1016/j.jcorpfin.2009.02.001

[17] Ho, P. H., Huang, C. W., Lin, C. Y., \& Yen, J. F. (2016). CEO Overconfidence and Financial Crisis: Evidence from Bank Lending and Leverage. Journal of Financial Economics, 120(1), 194-209. https://doi.org/10.1016/j.jfineco.2015.04.007

[18] Hribar, P., \& Yang, H. (2016). CEO Overconfidence and Management Forecasting. Contemporary Accounting Research, 33(1), 204-227. https://doi.org/10.1111/19113846.12144

[19] Larwood, L., \& Whittaker, W. (1977). Managerial myopia: Self-serving biases in organizational planning. Journal of Applied Psychology, 62(2), 194-198. https://doi.org/10.1037/0021-9010.62.2.194

[20] Malmendier, U., \& Tate, G. (2005). CEO Overconfidence and Corporate Investment. The Journal of Finance, $L X(6), 2661-2700$.

[21] Malmendier, U., \& Tate, G. (2008). Who Makes Acquisitions ? CEO Overconfidence and The Market's $\mathrm{s}$ Reaction. Journal of Financial Economics, 88(1), 20-43. https://doi.org/10.1016/j.jfineco.2007.07.002

[22] Malmendier, U., \& Tate, G. (2015). Behavioral CEOs: The Role of Managerial Overconfidence. Journal of Economi Perspectives, 29(4), 37-60.

[23] Malmendier, U., Tate, G., \& Yan, J. O. N. (2011). Overconfidence and Early-Life Experiences: The Effect of Managerial Traits on Corporate Financial Policies. The Journal of Finance, LXVI(5), 1687-1733.

[24] Mcintyre, M. L., Murphy, S. A., \& Mitchell, P. (2007). The top team: Examining board composition and firm performance. Corporate Governance: The International Journal of Business in Society, 7(5), 547-561. https://doi.org/10.1108/14720700710827149

[25] Miller, D. T., \& Ross, M. (1975). Self-Serving Biases in the Attribution of Causality : Fact or Fiction? Psychological Bulletin, 82(2), 213-225.

[26] Moore, P. . G. . (1977). The Manager 's Struggles with Uncertainty. Journal of the Royal Statistical Society, 140(2), 129-165.

[27] Niu, J. (2010a). The effect of CEO overconfidence on bank risk taking. Economics Bulletin, 30(4), 3288-3299.

[28] Niu, J. (2010b). The Effect of Overconfidence on the Sensitivity of CEO Wealth to Equity Risk. Journal of Financial Service Research, 38, 23-39. https://doi.org/10.1007/s10693-010-0081-8

[29] POJK Nomor 6/POJK.03/2016, Kegiatan Usaha dan Jaringan Kantor Berdasarkan Modal Inti Bank 1 (2016). www.ojk.go.id

[30] Pathan, S. (2009). Strong Boards , CEO Power and Bank Risk Taking. Journal of Banking and Finance, 33(7), 1340-1350. https://doi.org/https://doi.org/10.1016/j.jbankfin.2009.02.001

[31] Santi, F. (2016). Efek Overconfidence Manajer Terhadap Sensitivitas Pengaruh Arus Kas Pada Keputusan Investasi. Universitas Gajah Mada.

[32] Schrand, C. M., \& Zechman, S. L. C. (2012). Executive Overconfidence and The 
Slippery slope to Financial Misreporting. Journal of Accounting and Economics, 53(12), 311-329. https://doi.org/10.1016/j.jacceco.2011.09.001

[33] Skala, D., \& Weill, L. (2018). Does CEO Gender matter for bank risk? Economic System, 42(1), 64-74. https://doi.org/https://doi.org/10.1016/j.ecosys.2017.08.005

[34] Svenson, O. (1981). Are We All Risky and More Skillful Than Our Fellow Drivers? Acta Psychologica, 47, 143-148. 